\title{
The Study of Fish Supplement and Butterfat Substitute Effect on Expiry Date of Processed Cheese Product
}

\author{
Nataliya S. Lotysh \\ Saint-Petersburg National Research University of Information Technologies, Mechanics and Optics/ \\ The Institute of Refrigeration and Biotechnologies, 191002, Saint-Petersburg, Lomonosova St, 9, Saint-Petersburg, Russia \\ Email:n.lotysh@mail.ru
}

Tamara P. Arseneva

\begin{abstract}
Saint-Petersburg National Research University of Information Technologies, Mechanics and Optics/ The Institute of Refrigeration and Biotechnologies, 191002, Saint-Petersburg, Lomonosova St, 9, Saint-Petersburg, Russia Email: tamara-arseneva@mail.ru
\end{abstract}

\section{Doi:10.5901/mjss.2015.v6n2s4p13}

\section{Abstract}

The sector of functional products has top-priority meaning - it is the most convenient and natural form of introduction and enrichment of the human organism with vitamins, mineral substances, microelements and other components.Attraction into the branch of raw materials of non-milk origin - fish supplements and substitutes of butterfat - served the basis of technology development of processed cheese products of combined content, which in accordance with acting terminology are called processed cheese products. The technology of processed cheese products allows easily regulating their content by introduction of corresponding supplement that facilitates obtainment of product with set properties and content. Inclusion of meat and fish as the raw materials in the processed cheese content results in enrichment of the product with macro- and microelements, unsaturated fatty acids, except for regulation of fatty acid content of cheese products is executed by substitution of butterfat by butterfat substitute.

Keywords: fish supplements, functional products, processed cheese product, substitute of butterfat

\section{Introduction}

For the last 20-30 years the views on the role of fats in nutrition has radically changed. The role of polyunsaturated fatty acids and phospholipids in prophylaxis and treatment of lipid exchange disorders, in particular atherosclerosis, was established and scientifically proved [1].

In the issues of rationalization of the fatty composition content, the great attention is paid to correlation of fatty acids. The relation of linoleic acid to linolenic one should compose no less than 7 linoleic to no less than 0.25 linolenic one.

The substitutes of butterfat have well-balanced content. Their fatty-acid structure is maximally closed to the norms of saturated, polyunsaturated and monounsaturated fatty acids according to the content, and also according to the content of polyunsaturated fatty acids of omega- 3 and omega- 6 family.

The usage of high-quality substitutes of butterfat in combination with high-quality food supplements allows purposefully regulation of the product content, and consequently, its properties, receiving the products with balanced fatty-acid content, which corresponds to the healthy nutrition principles.

Inclusion of fish meat and cod-liver oil as the raw materials into the content of processed cheese products results in enrichment of the product with macro- and microelements, unsaturated fatty acids.

Presently the average statistical value of fish consumption by Russia's population can be considered as $17.2 \mathrm{~kg}$ per human a year. The consumption norm recommended by the Ministry of Health Care of RF is 18-22 kg [1].

The value of fish, as the food product is determined by presence of complete proteins and digestible fats, and also considerable content of vitamins and mineral resources in its meat content.

The proteins are complete, as they contain all irreplaceable aminoacids and are assimilated by human organism for $98 \%$. The protein content facilitates from 13 to $22 \%$.

The fats in fish meat contain about $86 \%$ unsaturated fatty acids (linoleic, linolenic, arachidonic). Such set of acids 
promotes to elimination of excess of cholesterol and improve metabolism in the human organism. The content of fat in fish is from 0.4 to $35 \%$.

Wisely balanced compounding of processed cheese products allows except for expansion of assortment receive the products of improved quality for different age groups, including for therapeutic and prophylactic nutrition.

At the development of compounding of processed cheese products with regulated fatty-acid content the basic task is to close the correlation of fatty acids in product with recommended ones by SRI of Nutrition.

\section{Method}

We conducted studies and developed technology of production of the processed cheese product with regulated by fattyacid content with fish supplements. Based upon the experiments conducted, the processed cheese product with butterfat substitute for $50 \%$ and dose of introduced fish supplement equal to $4-5 \%$ was selected. Half-finished products of salmon, lax and trout were chosen as the fish supplement.

It was detected that usage of half-finished lax or trout, or salmon with introduction dose from 4-5\% not only enrich the cheese product with functional ingredients, but gives the original and pleasant taste cast to the product.

There are much more $(63.9-70.1 \%)$ saturated fatty acids in the butterfat content than unsaturated ones $(29.9$ $36.1 \%$ ), so with the purpose of closing the content of butterfat lipid fraction to optimal correlation between saturated, monounsaturated and polyunsaturated fatty acids, the butterfat substitute "Soyuz 60E" was chosen.

At $50 \%$ substitution of butterfat with "Soyuz 60E" substitute, the processed cheese with weight part of fat $60 \%$ has expressed taste and greasing and binding consistent typical for this kind of processed cheese products[2].

The further studies were conducted by means of observation and comparison of quality parameters of experimental sample of the processed cheese product with control sample of processed cheese.

The study of fatty-acid content of control and experimental samples was conducted in the laboratory of FBI "TestS.-Petersburg".

\section{Results}

The fatty-acid content of processed cheese product with fish supplements (experimental sample with butterfat substitute) in comparison with (control processed cheese with butterfat) are represented in Table 1.

Table 1. The comparative characteristics of fatty-acid content in experimental and control samples

\begin{tabular}{|c|c|c|}
\hline $\begin{array}{c}\text { Fatty-acid content of triglycerides of fat, \% to } \\
\text { the acid amount }\end{array}$ & $\begin{array}{c}\text { Sample of fat, extracted from the } \\
\text { experimental product }\end{array}$ & $\begin{array}{c}\text { Sample of fat, extracted from the } \\
\text { control sample }\end{array}$ \\
\hline Butyric $\mathrm{C}_{4-0}$ & 1.6 & 3.6 \\
\hline Caproic $\mathrm{C}_{6-0}$ & 1.3 & 1.9 \\
\hline Caprylic $\mathrm{C}_{8-0}$ & 1.0 & 1.6 \\
\hline Capric $\mathrm{C}_{10-0}$ & 2.3 & 3.0 \\
\hline Decenoic $\mathrm{C}_{10: 1}$ & 0.2 & 0.2 \\
\hline Lauric $\mathrm{C}_{12: 0}$ & 1.7 & 11.5 \\
\hline Myristic $\mathrm{C}_{14: 0}$ & 8.5 & 1.9 \\
\hline Myristoleic $\mathrm{C}_{14: 1}$ & 0.9 & 32.0 \\
\hline Palmitic $\mathrm{C}_{16: 0}$ & 28.7 & 2.2 \\
\hline Palmitoleic $\mathrm{C}_{16: 1}$ & 1.4 & 12.9 \\
\hline Stearic $\mathrm{C}_{18: 0}$ & 8.3 & 22.2 \\
\hline Oleic $\mathrm{C}_{18: 1}$ & 30.9 & 3.3 \\
\hline Linoleic $\mathrm{C}_{18: 2}$ & 11.7 & 0.4 \\
\hline Linolenic $\mathrm{C}_{18: 3}$ & 1.2 & 0.2 \\
\hline Arachic $\mathrm{C}_{20: 0}$ & 0.2 & 0.2 \\
\hline Behenic $\mathrm{C}_{22: 0}$ & 0.1 & \\
\hline
\end{tabular}

As it is seen from the data represented in Table 1, the developed processed cheese product according to correlation of polyunsaturated fatty acids of omega-3 and omega- 6 families is closed to functional fatty products of mass consumption, recommended by the World Health Organization (FAO/WHO) and Nutrition Institute of RAMS.

Also medium-chain fatty caproic, caprylic and capric acids, peculiar to butterfat and necessary for normal life 
activity of human organism are included into the content of the processed cheese product with fish supplements.

All BS (butterfat substitutes) have high oxidation stability (considerably higher, than butterfat) owing to natural antioxidant vitamin E, which enters into the BS content that allows producing products, which have stable quality at the long-term storage.

The expiry terms of processed cheese products were established in the course of experimental studies. The experimental and control samples with weight part of fat $60 \%$ were put for storage at temperature $2-4{ }^{\circ} \mathrm{C}$ and relative air humidity no more than $85 \%$. The evaluation of quality parameters was conducted in each 10 days during 90 days.

Taking into account that according to organoleptic parameters essential changes during 70 days in the experimental and control samples were not observed with exception of taste and consistence change in the control sample for 80 days, in the Table 2 the data on $10^{\text {th }}$ and $90^{\text {th }}$ day of storage were stated [3].

The change of physicochemical parameters during the storage term also wasn't observed with exception of weight part of moisture. The physicochemical parameters of the experimental and control samples are stated in Table 3. The parameters of weight part of moisture in each 30 days of storage are stated in Table 4.

The processed cheese product relates to colloidal capillary-porous solids. The free water in colloidal system represents intercapillary liquid that possess ordinary properties of water. The other part is in more bound state. The bounded water is distinguished by the range of peculiarities, which partially suppress in evaporation. It was established that the stronger the water is bounded with the product component, the lesser it is able to participate in the processes that leads to reduction of its quality indicators.

Table 2. Organoleptic parameters of experimental and control samples

\begin{tabular}{|l|l|l|}
\hline \multirow{2}{*}{ Product name } & \multicolumn{1}{|c|}{ Storage duration, days } \\
\cline { 2 - 3 } Experimental sample & \multicolumn{1}{|c|}{10} & \multicolumn{1}{|c|}{90} \\
\hline & $\begin{array}{l}\text { Very expressed taste and aroma with fish aftertaste. } \\
\text { Consistence typical for pasty-mass processed } \\
\text { cheese product, greasing with presence of fish } \\
\text { particles. } \\
\text { The colour from white to weakly-yellow with present } \\
\text { of particles, typical for fish colour. }\end{array}$ & $\begin{array}{l}\text { Very expressed taste and aroma with fish aftertaste. } \\
\text { Consistence typical for pasty-mass processed cheese } \\
\text { product, greasing with presence of fish particles. } \\
\text { The colour from white to weakly-yellow with present of } \\
\text { particles, typical for fish colour. }\end{array}$ \\
\hline \multirow{2}{*}{ Control sample } & $\begin{array}{l}\text { Very expressed taste and aroma } \\
\text { Consistence typical for pasty-mass processed } \\
\text { cheese, greasing } \\
\text { Weakly-yellow colour }\end{array}$ & $\begin{array}{l}\text { Insufficiently expressed taste and aroma } \\
\text { Slightly refractory, a little adhesive consistence } \\
\text { Weakly-yellow colour }\end{array}$ \\
\hline
\end{tabular}

Table 3. Physicochemical parameters of experimental and control samples

\begin{tabular}{|c|c|c|c|}
\hline Product name & Mass part of fat in the dry substance, $\%$ & Mass part of moisture, $\%$ & Active acidity, $\mathrm{pH}$ \\
\hline Experimental sample & 60 & 57.8 & 6.02 \\
\hline Control sample & 60 & 58.2 & 6.0 \\
\hline
\end{tabular}

Table 4. The change of mass part of moisture in the storage process

\begin{tabular}{|c|c|c|c|}
\hline \multirow{2}{*}{ Product name } & \multicolumn{3}{|c|}{ Storage duration, days } \\
\cline { 2 - 4 } & 30 & 60 & 90 \\
\cline { 2 - 4 } & \multicolumn{3}{|c|}{ Weight part of moisture, (\%) } \\
\hline Experimental & 57.8 & 57.3 & 57.0 \\
\hline Control & 58.2 & 57.5 & 56.3 \\
\hline
\end{tabular}

As it is seen from the data represented in Table 3, the usage of fish at development of the processed cheese products reduces the loss of moisture in the product more than in twice (the moisture loss in the experimental sample is $0.8 \%$, while in control sample -1.9\%) that in its turn influence on the stable quality of organoleptic and physicochemical product parameters during the whole period of storage.

The results of study of microbiological parameters of samples for the end expiry term (90 days) are represented in Table 5; they don't exceed the permissible norms. 
Table 5. Microbiological parameters of experimental and control samples on $90^{\text {th }}$ days

\begin{tabular}{|c|c|c|c|c|}
\hline Product name & $\begin{array}{c}\text { QMAFAnM, } \\
\mathrm{CFU} \cdot \mathrm{g}^{-1}, \text { no more }\end{array}$ & $\begin{array}{c}\text { Product weight, } \mathrm{g} \text { in which colibacillus group } \\
\text { bacteria were not detected (coliforms) }\end{array}$ & $\begin{array}{c}\text { Mould, CFU } / \mathrm{cm}^{3} \cdot \mathrm{g}^{-1}, \\
\text { no more }\end{array}$ & $\begin{array}{c}\text { Yeast, CFU/ } \mathrm{cm}^{3}(\mathrm{~g}), \\
\text { no more }\end{array}$ \\
\hline Experimental & $3.5 \times 10^{3}$ & 0.1 & 20 & 29 \\
\hline Control & $3.8 \times 10^{3}$ & 0.1 & 15 & 31 \\
\hline
\end{tabular}

\section{Conclusions}

Based upon the conducted experimental studies it is possible to make the following conclusions:

- It was found that at storage of the processed cheese product with using fish supplement and butterfat substitutes the quality parameters during the whole term of storage (90 days) are not changed, which in the control sample the quality indicators didn't change during 70 days. The stability of processed cheese product quality is connected with good water-retaining ability of fish half-finished product and high oxidative stability of butterfat substitute.

- Expiry terms of processed cheese production with fish supplements during 90 days at storage temperature 2$4^{\circ} \mathrm{C}$ and relative humidity of air no more than $85 \%$ were established. However, being guided by the methods of calculation of expiry term (Hygienic evaluation of the expiry terms of food products), the expiry terms are 60 days.

\section{References}

Appalonova, I.V., Smirnova, E.A., Nikonorova, N.P. (2012). The Study of Fatty-acid Content of Milk Lipids, Pishchevaia Promyshlennost', 11, pp. $72-75$.

Khurshudian, S.A., Smirnova, E.A. (2008). The Role of Organoleptic Analysis in Identification of Food Products, Pishchevaia Promyshlennost', 12, pp. 38-39.

Liakh, V.Y., Shergina, I.A., Sadovaia, T.N. (2011). Cheesemaking Reference-book, Professia, SPb., P. 680.

Pavlova, I.V., Dolganova, N.V., Kravchenko, E.V., Dotsenko, E.V., Koblitskaia, M.B. (2013). The Issues of Technical Regulation in the Area of BS Production, Molochnaia Promyshlennost', 8, 10-11.

Roshchupkina, N.V. (2006). The Technology of Processed Cheese Products, Pererabotka Moloka, 5, 18-19.

Roshchupkina, N.V. (2008). EFKO Food Ingredients: Expands the Line of Fats With Low Content of Trans Isomers, Molochnaia Promyshlennost', $5,71$.

Stepanova, L.I. (2010). Butterfat Substitutes SDS and SOYUZ - Quality Guarantee of Our Products, Molochnaia Promyshlennost', 10, 48-49.

Tamim, A.J. (2013). Processed Cheese and Cheese Products (Editor-author Tamim, A.J.), transl. from English. SPb.: Professia, P. 376.

Zajtseva, L.V. (2011). New Era: Substitutes of Butterfat According to GOST, Food Industry, 3, 50-51;

Zajtseva, L.V. (2012). Trans Isomers - the Plague of XXI Century, Pishchevaia Promyshlennost', 3, 28-31. 